\title{
Kunisov sindrom
}

\section{Kounis syndrome}

Jelena Vucković-Filipović, Srdjan Milanov, Violeta Irić-Čupić, Vladimir Miloradović, Ivan Simić, Goran Davidović

Klinika za kardiologiju, Klinički centar „Kragujevac“, Kragujevac

PRIMLJEN 25.03.2015.

PRIHVAĆEN 14.07.2015.

\section{SAŽETAK}

Kunis sindrom predstavlja grupu simptoma koji se manifestuju kao nestabilna vazospastična ili ne-vazospastična angina, ili čak kao akutni infarct miokarda. Zapaljenski marker koji se oslobađaju tokom alergijskih reakcija su najčešće okidač za nastanak Kunis sindoma. Predstavljen je slučaj 79-ogodišnjeg muškarca sa akutnim infarktom miokarda nastalim nakon alergijske reakcije usled ujeda pčele.

Ključne reči: ujedi insekata i ubodi; preosetljivost, neposredna; infarkt miokarda.
Jelena Vuckovic-Filipovic, Srdjan Milanov, Violeta Iric-Cupic, Vladimir Miloradovic, Ivan Simic, Goran Davidovic

Clinic of Cardiology, Clinical Centre „Kragujevac“, Kragujevac, Serbia

RECEIVED 25.03.2015

ACCEPTED 14.07.2015.

\section{ABSTRACT}

Kounis syndrome is a group of symptoms manifested as unstable vasospastic or non- vasospastic angina, or even as acute myocardial infarction. Inflammatory mediators released into a bloodstream during some allergic reaction are most frequently mentioned to be a trigger for Kounis syndrome. We present a case of acute myocardial infarction associated with an allergic reaction after a honeybee sting, in an 79-year-old Serbian male.

Key words: insect bites and stings; hypersensitivity, immediate; myocardial infarction. 


\section{CASE REPORT}

A 79-year-old male was admitted to Emergency room in Clinical Centre Kragujevac two hours after he was stung on the thumb of his left leg by honeybee while working on his field. After stinging he had a short period of dizziness and respiratory discomfort without loss of consciousness. After a while he felt sudden chest pain, itching, dyspnea and fatigue so he was transffered to our hospital by his relatives. A history of treated arterial hypertension and consumation of alcohol were present. He was non-smoker, with no history of dyslipideamia, diabetes mellitus, coronary artery disease or other significant illness, and dennies previous allergy, rhinitis, bronchial asthma, dermatitis or eczema.
On arrival he was consciousness, well oriented, afebrile and slightly cyanotic. His blood pressure was 105/60 $\mathrm{mmHg}$, and the pulse was $90 / \mathrm{min}$ regular. Auscultation of the lungs and heart revealed normal breathing sound, rhythmic heart action with clear sounds. He had a erythematous rash on the left foot with a mild edema. Examination of other organ systems showed no abnormality.

An electrocardiogram performed immediately revealed sinus rhythm, heart rate was $89 / \mathrm{min}$, with 1-1.5 mm ST-segment elevation in leads II, III, aVF, 2 mm depression of STsegment with biphasic T wave in leads V2 and V3 (Figure 1). With the diagnosis of ST-segment elevation myocardial infarction he was transferred to Coronary Unit.

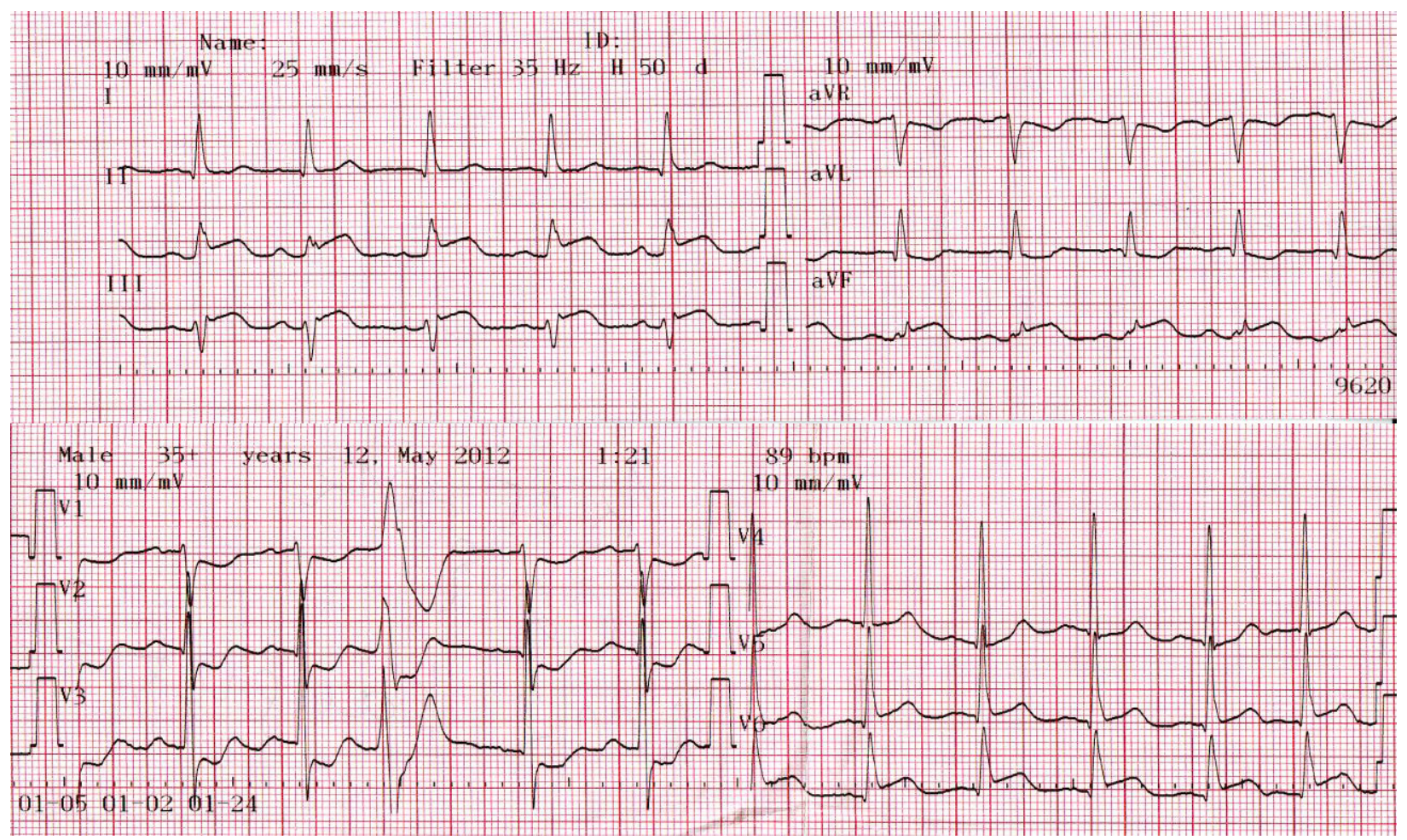

Figure 1. Initial ECG - ST-segment elevation in leads II, III, aVF, depression of ST-segment with biphasic T wave in leads V2 and V3, occasional PVCs

Initial laboratory analysis showed rise in Troponin I levels (34.68), CK-MB (49.3), markers of inflammation (leukocytosis $\left(\mathrm{WBC}=17.9^{\star} 109 / \mathrm{L}\right)$ with predomination of eosinophils - 15\%), CRP - $65 \mathrm{mg} / \mathrm{L}$; fibrinogen - $5.879 \mathrm{~g} / \mathrm{L}$ ), mild hyperglycemia $(10.2 \mathrm{mmol} / \mathrm{l})$. All other laboratory findings were inside the reference range. Echocardiography revealed mild left atrial and ventricle dilatation (LA $43 \mathrm{~mm}$, EDDLV $60 \mathrm{~mm}$; ESDLV $44 \mathrm{~mm}$ ), severe hypokinesis of posterior wall, mild hypokinesis of basal segment of inferior left ventricle wall and mild hypokinesis of basal segment of ventricle septum. Due to a suspicion on Kounis syndrome we consulted alergologist who suggested additional laboratory analysis (histamine, immunology with the accent on IgE antibodies, complement component C).

Patient recieved dual antiplatelet therapy and sent to primary PCI. Coronarography revealed significant stenosis of distal right coronary artery (RCA) branch - posterolateral artery (PLA) (Figure 2). During the procedure aspiration of fresh thrombus was made and extracted thrombus was sent to $\mathrm{PH}$ analysis with hematoxilin-eosin, which revealed the presence of eosinophils. 


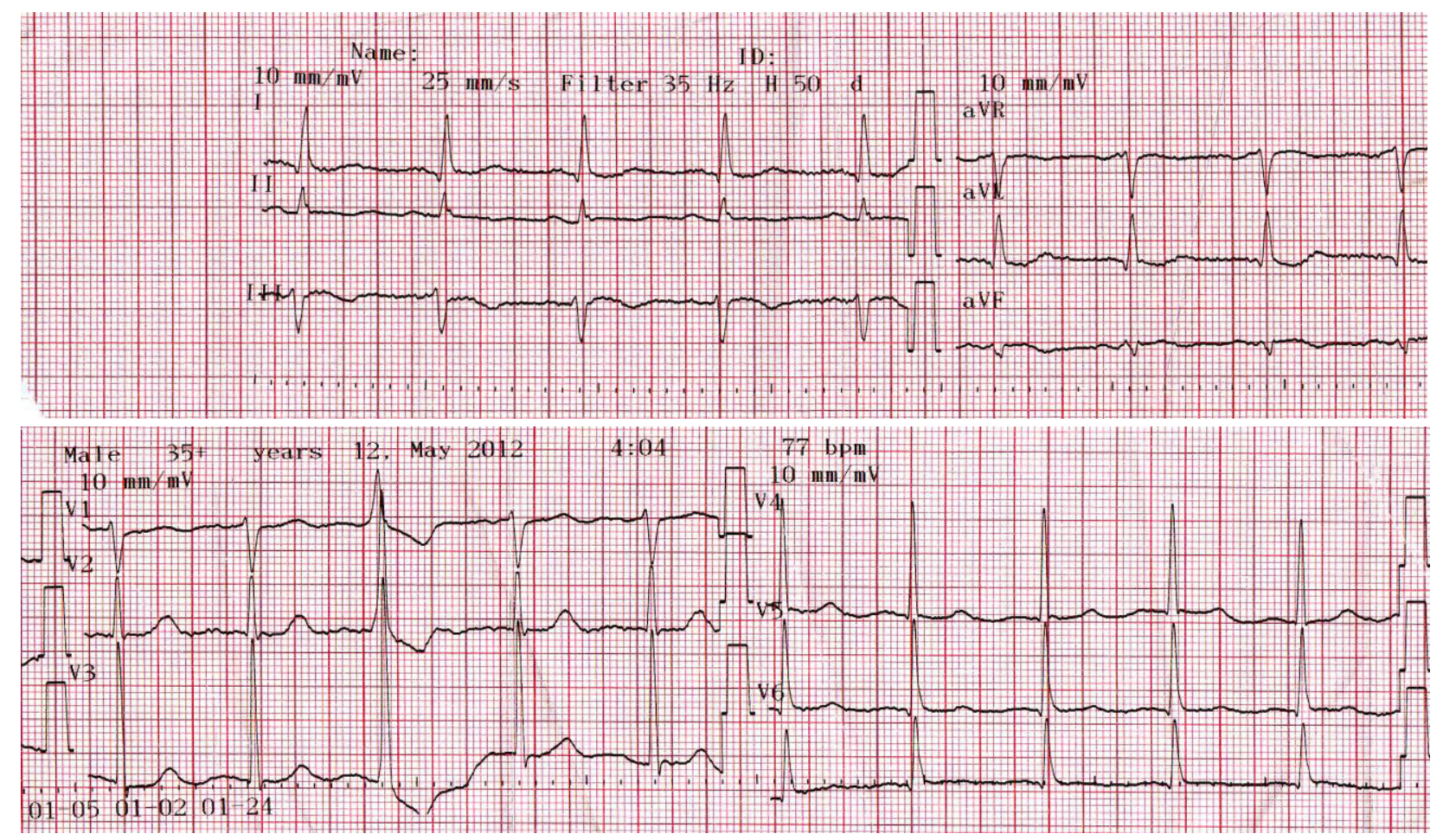

Figure 2. ECG after PCI - resolution of initial ECG changes

Results of additional laboratory parameters confirmed the presence of allergic reaction (histamine $-2.7 \mathrm{ng} / \mathrm{mL}$; with $\mathrm{IgE}$ and complement component $\mathrm{C}$ above normal range).

During the hospitalization we administrated dual antiplatelet therapy, anticoagulant therapy, beta blockers (after normalization of blood pressure), $\mathrm{H} 1$ inhibitors, corticosteroids (methylprednisolone). After stent was implanted there

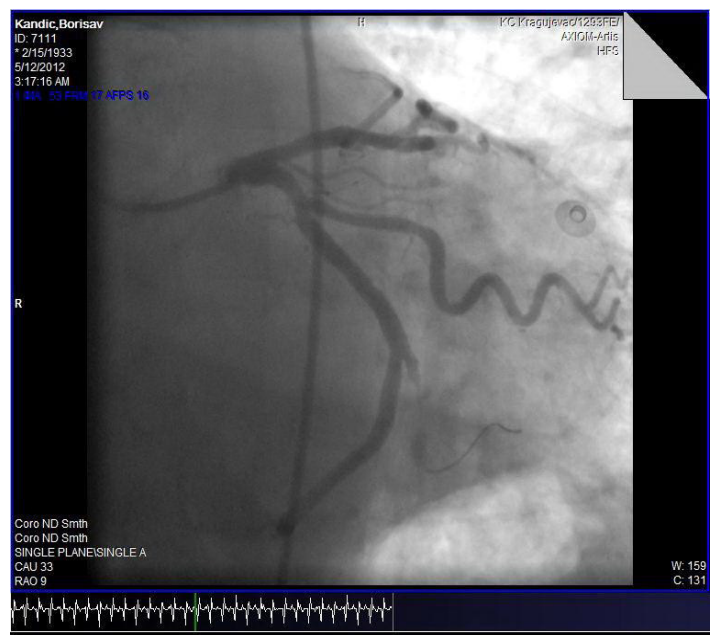

was a significant resolution of ECG changes, over 50\%, followed by clinical improvement and diminishing the angina discomfort.

During the hospital follow-up he had a complete resolution in ECG changes (Figure 3) as well as decrease in cardio specific enzymes (troponin I - 0.260 $\mu \mathrm{g} / \mathrm{L}$; CK-MB -23.1 $\mathrm{U} / \mathrm{L})$. Patient was discharged after 5 days with advice to attend 3 and 6-month follow-up controls.

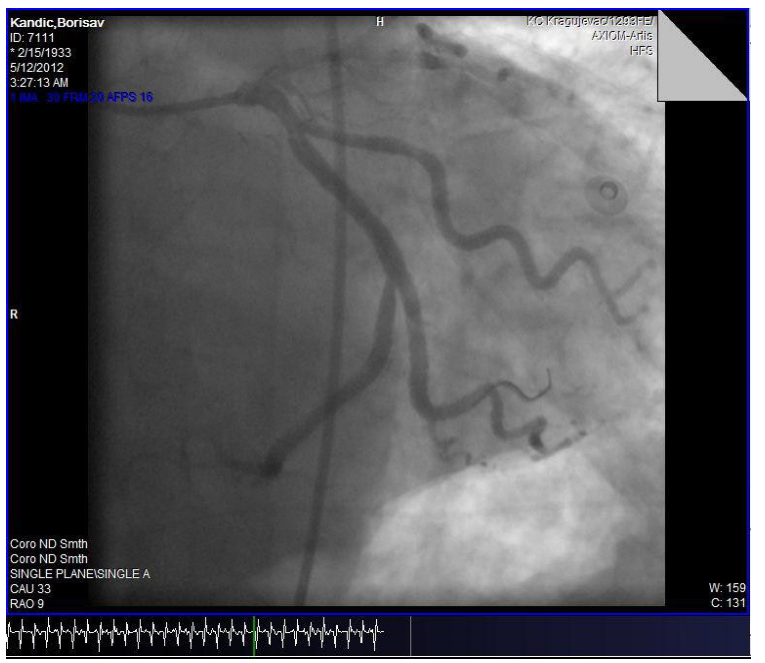

Figure 3. Coronarography findings PLA stenosis 


\section{DISCUSSION}

Kounis syndrome was named after a Greek author, Kounis, who was first to describe the progress of allergic angina into acute myocardial infarction. In 1991 syndrome was described by Kounis and Zavras ${ }^{1}$ as "the coincidental occurence of chest pain and allergic reactions accompanied by clinical and laboratory findings of classic angina pectoris caused by inflammatory mediators released during the allergic insult". Later, in 1995, Kovanen investigated the specificity of coronary arteries in patients who died after acute myocardial infarction, and have found that they had more significant mastocyte degranulation in eroded or ruptured plaque area than in nearby cells ${ }^{2}$. Constantinidis showed that even some common allergic reactions could provoke plaque rupture ${ }^{3}$, which happened with our patient who experienced acute myocardial infarction after he was stung by honeybee.

In 1998, Braunwald ${ }^{4}$, in his editorial, categorized allergic angina as a subgroup of dynamic coronary occlusive lesions induced by allergic reactions noting that vasospastic angina can be induced by ,allergic reactions with mediators such as histamine or leukotriens acting on coronary vascular smooth muscle“. As previously described, blood histamine levels can be elevated in patients suffering from different types of ischaemic heart disease ${ }^{5}$ including Kounis syndrome.

Today, Kounis syndrome is described as the occurence of acute coronary syndrome with mast cell activation induced by allergic or hypersensitivity and anaphylactoid reactions. It can manifest as unstable vasospastic or nonvasospastic angina, and even as acute myocardial infarction triggered by the release of inflammatory mediators ${ }^{6}$. Our patient had a typical allergic reaction to honeybee sting followed by angina pain and development of myocardial ischaemia with histamine increase.

There are two types of Kounis syndrome described so far with a proposition to include the third variant in a current classification. Type I refers to patients without cardiovascular risk factors and with healthy coronary arteries in whom allergic insult triggers coronary vasospasm that causes chest pain, ischaemic changes on electrocardiogram and normal/elevated markers of myocardial damage. This can be manifestation of endothelial dysfunction or microvascular angina ${ }^{7}$.

Type II occurs in patients with pre-existing coronary disease where mediators may induce coronary vasospasm with normal cardiac enzymes, or erosion/rupture of the atheromatous plaque, resulting in acute myocardial infarction 8,9 . We classified our patient into type II Kounis syndrome according to his findings. Inferior myocardial infarction was shown on ECG as ST- segment elevation in inferior leads and confirmed by hypokinetic inferior wall on electrocardiography. Severe hypokinesis of posterior wall was present because of the occlusion of posterolateral branch of right coronary artery.

Type III, that has been proposed in recent years, refers to patients with drug-eluting stent thrombosis with the presence of mast cells and eosinophils revealed with Giemsa ad hematoxylin-eosin staining ${ }^{10,11}$.

We administrated therapy according to acute coronary syndrome protocol plus type I Kounis treatment (corticosteroids, $\mathrm{H} 1$ and $\mathrm{H} 2$ blockers, dual antiplatelet and anticoagulant therapy). Although beta blockers should be administrated carefully because they can exaggerate coronary spasm, we had to administrate them because of tachycardia and occasional PVCs in our patient.

Several causes have been reported as capable of inducing Kounis syndrome. These include some drugs, foods and insects stings. In the case of insect stings and bites, the venom or saliva contains proteins, peptides and vasoactive amines that can cause direct cardiotoxicity but also behave as allergens, with activation and degranulation of the mast cells, resulting in the release into the systemic bloodstream of a number of vasoactive mediators and proteases. The existence of mastocytes in heart tissue and their participation in the anaphylactic reaction that triggers tachycardia, coronary vasoconstriction, dysfunctional ventricular contractility and blockade of atrioventricular conduction was already demonstrated ${ }^{12,13}$. 


\section{LITERATUR}

1. Kounis NG, Zavras GM. Histamine-induced coronary artery spasm: the concept of allergic angina. Br J Clin Pract 1991; 45: 121-8.

2. Kovanen PT, Kaartinen M, Paavonen T. Infiltrates of activated mast cells at the site of coronary atheromatous erosion or rupture in myocardial infarction. Circulation 1995;92:1083-8

3. Constantinides P. Infiltrates of activated mast cells at the site of coronary atheromatous erosion or rupture in myocardial infarction. Circulatory 1995;92:1083

4. Braunwald E. Unstable angina: an etiologic approach to management. Circulation 1998; 98: 2219-22.

5. Zdravkovic V, Pantovic S, Rosic G, Tomic-Lucic A, Zdravkovic N, et al. Histamine blood concentration in ischaemic heart disease patients. J Biomed Biotechnol 2011; http://dx.doi.org/10.1155/2011/315709

6. Kounis Ng. Kounis syndrome (allergic angina and allergic myocardial infarction): A natural paradigm? Int J Cardiology 2006; 110: 7-14.

7. Cepeda PR, Herrejon EP, Rodriguez Aguirregabiria MM. Kounis syndrome. Med Intensiva 2012; 36 (5): 358-64.
8. Biteker M, Duran NE, Biteker F. Kounis síndrome: first series in Turkish patients. Anadolu Kardiyol Derg 2009; 9: 59-60.

9. Nikolaidis LA, Kounis NG, Gradman AH. Allergic angina and allergic myocardial infarction: a new twist on an old síndrome. Can J Cardiol 2002; 18: 508-51.

10. Chen JP, Hou D, Pendyala L, Goudevenos JA, Kounis NG. Drug-eluting stent thrombosis: the Kounis hypersensitivity-associated acute coronary syndrome revisited. JACC Cardiovasc Interv 2009; 2: 583-93.

11. Lopez PR, Peiris AN. Kounis syndrome. South Med J 2010; 103: 1148-55.

12. Puttegowda B, Chikkabasavaiah N, Basavappa $\mathrm{R}$, Khateeb ST. Acute myocardial infarction following honeybee sting. BMJ Case Rep 2014; Apr 12; 2014: pii: bcr2014203832. doi: 10.1136/bcr-2014-203832 (http:// www.ncbi.nlm.nih.gov/pubmed/24729117)

13. Yang HP, Chen FC, Chen CC, Shen Ty, Wu SP, Tseng YZ. Manifestations mimicking acute myocardial infarction after honeybee sting. Acta Cardiol Sin 2009; 25: 315 . 